\title{
The Role of Principal's Power and Teacher Empowerment
}

\author{
Erida Elmazi (PhD Candidate) \\ University of Tirana/Faculty of Economy, Albania
}

\begin{abstract}
Principals are a key factor on various aspects of schooling, and teachers play a determinant role on student's achievement. Several statistical studies have shown this significance. Fewer findings are about the power relationship that exists between the principal and the teachers. The role of effective use of power and empowerment initiatives is not clear.

This paper focuses on investigating the relationship among the principal's bases of power, and the role of power in effective teacher and teacher empowerment. For the current study, the primary data source used was a survey. The sample comprised of 20 principals and 100 teachers in High Schools in Albania. Results of the study indicate that correlation exists between "staying on top" and level of power. Findings show also that there does not exist a general organizational climate that encourages empowerment and delegation The data suggests that most teachers perceive their principals as operating from a legitimate power base.
\end{abstract}

Keywords: Power, principal, teacher, empowerment

\section{Introduction}

The study of educational leadership has emerged as a major field of social and educational research. This is attributed to the importance of education, as it is widely considered to be crucial to the survival and success of individuals and developing countries. In building a good school, the most important factor is effective leadership (Dalal \& Rani, 2013). Nowadays, several expectations and responsibilities have been placed over schools, which have created the need for a very effective school leadership with a new style of leading. Autocratic and hierarchical leadership is old fashioned. Schools need a much different leadership style, where the power is not concentrated only on one hand, but its distribution is critical and fundamental for the effectiveness of a principal. Teacher empowerment is very important due to the significant role it plays on student learning. School leaders indirectly 
improve teaching and learning through their influence on motivation, engagement, and working conditions of teachers (Louis et al., 2010).

When the word "power" was mentioned, the first thing that is perceived is the ability to influence the others to do what you want. It implies leading and following, dominance, and subordination. Generally, the most suitable environment for this concept has been described to be politics, and then the corporate and business environment. However, it may sound strange for someone to hear this word in the context of education, which is related with learning, acquisition of knowledge, development of skills, values, etc. Describing the principal and teacher, the first one is dependent on the desire for power, while the second one is dependent on empowerment. Thus, this may sound very strange to the students and their parents. In fact in the context of school culture and school performance, it is very important to study the relation between principal and teachers and the role of power. The main scope of this article is to throw light on the usage of power by the principal, the most used power bases, and to ascertain their role in the teacher's effectiveness.

Through this study, we aimed to test the following hypothesis:

- $\quad$ There exists a correlation between the power and hierarchical level of principals and teachers within the organization.

- $\quad$ There do not exist a general organizational climate that encourages empowerment and delegation.

\section{Power}

Power is a very complex topic. Apart from the fact that you have to be very precise in the use of language, there is also a different requirement that the wording should be cross-linked with each other (Zogjani, Llaci, \& Elmazi, 2014). The concept of "power" in everyday language and in political science is close to the concepts of influence, violence, authority, rule, and control (Feraj, 2004). Neither ordinary people nor scholars agree on how to use these terms. The "influence" of a writer is the "power" of another (Dahl, 1991). So although the influence and the power go hand in hand with each other, and forms the basis of the leadership structure, they are not the same thing. What is the power? This is exactly one of the many theoretical questions that aims to unify the whole phenomenon. In seeking to conceptualize it, lets look at the root meanings of the word. The word "power" itself, just as its appreciation in Greek "dynamitis", or the Latin word "potentia" with its modern derivatives, or the German word "Macht", shows its "potential" character (Arendt, 2006). From the etymological point of view in Latin, it relates to the concept of opportunity. Thus, in French, "power" is translated "pouvoir" which means "can" or "you can do". In Albanian, the term "power" may originate from the Latin term 'potestas' and it might have entered into Albanian vocabulary at the same time with many other terms within a religious context. Usually in the 
texts of Albanian customary law, power is conceived as a "right authorized for" (Hasimja \& Papa, 2008).

Krausz (1986) argued that "power is the ability to influence the actions of individuals or groups and is understood as the leader's influential potential." Etzioni (1964) and French and Raven (1968) described it as the vehicle that leaders influence followers. According to Rees and Porter (2008), power can be defined as the ability to influence people, information, and material resources to achieve something. Power can also be defined as "having the discretion and means to apply asymmetrically one's will to others (Sturm \& Antonakis, 2014).

According to economist Keneth Ewart Boulding, human relations are classified as threatening, interchangeable, and integrating relationships. In his book, "Three Faces of Power," he emphasized the use of these three types of human relationships to distinguish between the concepts of 'power', 'impact or influence', and 'authority' among them in the form of three different judgments that lie in their foundation. The power would be expressed in the form of judgment: "Do what I want, or I will do something you do not want". Impact is expressed in the form of judgment: "Do something that I desire and I will do something you desire". The authority is expressed in the form of judgement: "I do what you are looking for, because it is you" (Boulding, 1989).

\section{Principal's Power and Teacher Empowerment}

A principal is the leader of the school and at the same time is the manager of the school. In the educational context, principals are among the key authorities that dispose power. Like all managers, school principals have to accomplish the organizational goals and do the work with and through teachers. This requires exercise of influence and power. Principals use power to influence the behavior of teachers and students (Lyons \& Murphy, 1994). According to several researchers, positive relationship between the principal and teachers evoke school success (Short \& Johnson, 1994; Brewster \& Railsback, 2003).

Moreover, power is thought of as a tool by which leaders influence followers (Etzioni, 1964). It is a universal phenomenon. The ability to lead through influence and persuasion is an effective leader's behavior, as it is an indispensable element of effective leadership. Scholars argue that power is shaped by several resources such as organizational and personal ones (French \& Raven, 1959), institutional and normative constraints (Etzioni, 1975; Blase, 1988), and by their personal experience and personality (Bandura, 1978; Kipnis, 1976). According to French and Raven (1959), conceptualization of social power consists of types or bases of power such as reward, coercive, legitimate, expert, and referent power. Reward power is based on the ability of the leader to provide rewards to followers. People who follow leaders that have 
the power to reward the belief that if they agree with the suggestions and opinions of the leader, this will result in positive incentives such as pay, promotion, or recognition. This kind of power is based on the kind of reward that the leader can provide to followers. Therefore, it is very important how attractive it will be for the followers to be rewarded.

Coercive power is the opposite of the reward power and it is based on fears and measures of austerity. The fear of being hurt allows people with the power of coercion to rule over those who are afraid. A leader who has a great power of coercion make others follow him by communicating that failure to obey him, which will lead them to retribution. The good use of punishment and other forms of aggravating can be seen in cases where behaviors that are important to the organization such as theft, illegal activities, deliberate disobedience to legitimate orders or legitimate needs have to be restrained and prohibited. Examples of coercive power are downsizing, threats of punishment, unwanted tasks, lack of salary increases, job dismissals, etc. The power of position or legitimate power is the kind of power that is based on the position or title held by the individual. This power is sanctioned by the organization. As a result, it is unstable and unpredictable, as someone's position in an organization cannot be eternal. If someone leaves the organization, the power remains there; so he does not follow the person. This kind of power materializes in title such as manager, vice president, director, supervisor, administrator, etc.

Expert power is based on follower's belief that the leader has knowledge, talent, and skills. It is the same as the authority that stems from knowledge. A leader who has a large expert power has the expertise to facilitate the work of others as he has technical, logical, analytical skills, experience, or has conducted various trainings. Referent power is based on the personal traits of the leader and on the need of others to connect with other influential people. Features such as charisma, elegance, and creativity are the real features of most of the leaders. They can promote respect and loyalty. A leader who has great referential power is liked and admired by others because of his personality. This admiration and identification with the leader influences others to act on the suggestions of the leader.

After this first taxonomy of power, later scholars suggested also two other types of power such as information and relationship power bases. Information power is based on the leader's ability to receive and provide valuable information that is needed for the organization or followers. Lack of this power obligates employees to be dependent of superiors for information needs. Power of relationships is based on the ability of the leader to build influential networks and alliances, inside and outside the organization. These seven power bases have been identified as the potential means of influencing others successfully. Thus, the effective use of power and the perceptions of power by 
follower are critical in determining leader's success and organizational advancement (Aguinis, Simonsen, \& Pierce, 1998).

The focus of power has changed from previous decades and has become more transformative and motivating at the same time, worldwide. From "having power over" teachers, the trend has transformed to "power sharing" with teachers in the framework of educational reform. Power sharing in the organization is critical to the effectiveness of a leader. It results in greater job performance and higher performance (Forster, 2005). Marks and Louis (1997) concluded that teacher empowerment is not a sufficient but a necessary condition for enhancing student academic performance. Empowerment is a relatively new concept and its importance was highlighted in the 80s of the last century as a response to economic and technological changes. Steven H. Appelbaum, Danielle Hébert, and Sylvie Leroux have studied the link between empowerment and power. Traditionally, principals have been held accountable for the effectiveness of schools as they work to influence the change process towards increased teacher involvement and empowerment (Rinehart et al., 1998).

Short and Rinehart (1992) stated that school improvement is dependent upon increased opportunities for staff to participate in the decision making process in vital areas within an organization. Empowering teachers to contribute to organizational goals is a prerequisite for making them effective. Empowering teachers means to develop, to train them to solve problems, to give them freedom, and to allow acting without requiring approval for any assignment. Michael Armstrong defines empowerment as the assurance that people are able to use and develop their skills and knowledge in ways that help them achieve their goals and organization (Koxhaj, 2006). Bolin (1989) stipulated teacher empowerment as "investing in teachers with the right to participate in the determination of school goals and policies and to exercise professional judgment about what and how to teach".

Effective principals enhance personal power by empowering teachers in the organization and at the same time they develop and enhance credibility and confidence. A principal as mentioned above is judged by the results of teachers. When a principal builds a motivated, enthusiastic, self-confident team, then he has built a strong result-based culture. The result is a proactive organization. Jamieson and O'Mara (1991) argued that: "As a manager who empowers others, you will behave as a colleague rather than as a boss, relying on influence, respect, and relationship to work with employees". Thomas and Velthouse (1990) found that empowerment was correlated positively with job satisfaction. A job that generates more pleasure may increase organizational engagement. Therefore, employees will want to stay longer in their job, have a higher attendance, a higher interest in the organization, and would be able to achieve its goals. Satisfaction affects other behaviors such as turnover. 
However, we know the costs that these behaviors carry and what they mean about the effectiveness of the organization.

Empower as explained by Short and Rinehart (1992) has three levels: principals seeking that teachers become part of decision making, using critical thinking to solve problems and to find solutions; the second level includes the opportunity for teachers to be trained through specialized programs; and the third level, in fact, includes discrepancies.

Over the years, the link between schools principal's power bases and its impact on effective teacher and empowerment has attracted the attention of researchers. According to Sayles (1964), Bass (1981), Yukl (1981), Gunn and Holdaway (1986) and Blase (1988), expert power of principals contributes positively to the psychological, social, and technical aspects of teacher work performance including satisfaction, loyalty, and commitment. On the others hand, scholars such as Tjosvold (1978) and McNeil (1978) showed a strong relationship between coercive oriented principal behavior and teacher. Quality management theorists such as Philip Crosby and W. Edwards Deming suggested that there is a decrease in productivity and creativity when exercising the power of coercion. Bredeson (1989) found that in schools with empowered teachers, principals positively affected teachers by being informed (expert power) and providing an open, friendly, and supportive environment (referent power). According to Drake and Roe (1999), reward by special praise and recognition has been the main source of praise used by principals; few teachers stand in awe of principals' legitimate power; and schools that rate the principal as having expert power received high scores for teacher morale, teacher satisfaction, and teacher performance. Sergiovanni and Starratt (2002) findings show that extrinsic rewards are not powerful enough to increase teachers' motivation. Lintner (2008) findings show that expert and referent powers have the greatest influence on their feelings of empowerment. On the contrary, reward power and coercive power bases had the least relationship to teacher empowerment.

\section{Background on the Educational System in Albania}

Over the past decades, governments have been trying to improve the education system in support of a higher student performance. Thus, educational system in Albania is transforming gradually. The pre-university education system has undergone a series of reforming changes, at the system level and in the teaching practice, through three main phases (Ministry of Education, Sports and Youth, Pre-university Education System Reform, 2014), namely:

- Correction phase of the education component (until 1995).

- Preparation phase for change, based on law no. 7952, dated 21.06.1995, "On the Pre-University Education System (1995-2010). 
- Further SAPU reformation phase, based on Law 69/2012, dated 21.06.2012 "On the pre-university education system" (2012 and onwards).

Like its neighbors in Europe and the Western Balkans, Albania sees the role of teachers and school leaders as a central role in improving learning outcomes and creating a more impartial and inclusive education system as a whole (UNESCO, 2017). Already, the Ministry of Education, Sports and Youth is implementing the Strategy for the Development of Pre-University Education and has undertaken a reform of the pre-university education system. This reform recognized the decisive role that the school director has on student performance, relationship with teachers, and community liaison. Also, it concentrates efforts on their training in order to learn the best practices of leadership theories. Albania continues to decentralize its education system and pursue policies that require greater autonomy in school. Furthermore, leaders will play an increasingly important role in both leading and delegating leadership to others (UNESCO, 2017). Training, increasing efficiency, and increasing expectations regarding school directors are becoming increasingly important. This move seems to follow the world trend based on the attention which is currently taking leadership in schools. Institute of Education Development (2016) has identified the needs of principals and teachers for training. The internship training for the professional development of teachers has been implemented for several years in the Albanian education system as well. It passes through 3 categories of working years in education, respectively 5 years, 10 years and 20 years. According to several teachers, it was argued that professional autonomy and self-motivated development is very limited.

\section{Methodology}

This study follows the investigation that was made by Prof. Zogjani, Prof. Llaci and me, for this similar topic in 30 Albanian companies in 2012. Now the study has been extended to the Albanian high schools and it intends to explore the usage of power in an educational context. Primary data source was used. The conducted questionnaire for this study, was borrowed by Centre for Creative Leadership in the U.S. based on the project "The Ideas2Action". The questionnaire contained 15 standardized questions. The sample consisted of 20 principals and 100 teachers in 20 Albanian High Schools. SPSS was used as the statistical program to find possible statistical links of variables taken into consideration. The hypotheses raised were tested by using several ways of analysis such as Linear Regression, Correlation, and Chi-square $\left(\chi^{2}\right)$ test.

\section{Findings and Discussion}

The findings of our research show that there exists a notable relation between the hierarchical position and the perceived level of power. Even in the educational context, the legitimate position of principals is strongly correlated 
with the high position that he holds. Teachers perceive moderate level of power. On the other hand, principals perceive being from moderately to extremely powerful. The coefficient of Pearson's $\mathrm{R}$ is -.773 and the significance is .000 . According to Table 1 , the observed statistics of chi-square test is 1.077 , with freedom degree 7 , proving that the hierarchical position affects moderately the amount of power. This is because the security level .000 is lower than 0.05. Therefore, this results in a positive test for our first hypothesis, which is confirmed.

Table 1. Coefficients ${ }^{\mathrm{a}}$

\begin{tabular}{|c|c|c|c|c|c|c|}
\hline \multirow{2}{*}{\multicolumn{2}{|c|}{ Model }} & \multicolumn{2}{|c|}{ Unstandardized Coefficients } & $\begin{array}{l}\text { Standardized } \\
\text { Coefficients }\end{array}$ & \multirow[b]{2}{*}{$\mathrm{t}$} & \multirow[b]{2}{*}{ Sig. } \\
\hline & & $\mathrm{B}$ & Std. Error & Beta & & \\
\hline \multirow[t]{2}{*}{1} & (Constant) & 11.170 & .406 & & 27.499 & .000 \\
\hline & Position & -2.870 & .217 & -.773 & -13.219 & .000 \\
\hline
\end{tabular}

a. Dependent Variable: Perceived power

Table 3. Correlations

Table 2. Descriptive Statistics

\begin{tabular}{|c|r|r|r|}
\hline & \multicolumn{1}{|c|}{ Mean } & \multicolumn{1}{c|}{$\begin{array}{c}\text { Std. } \\
\text { Deviation }\end{array}$} & \multicolumn{1}{c|}{$\mathrm{N}$} \\
\hline $\begin{array}{c}\text { Perceived } \\
\text { power }\end{array}$ & 5.91 & 1.390 & 120 \\
Position & 1.83 & .374 & 120 \\
\hline
\end{tabular}

\begin{tabular}{|cc|r|r|}
\hline & & $\begin{array}{c}\text { Perceived } \\
\text { power }\end{array}$ & Position \\
\hline $\begin{array}{c}\text { Perceived } \\
\text { power }\end{array}$ & $\begin{array}{c}\text { Pearson } \\
\text { Correlation } \\
\end{array}$ & 1 & $-.773^{* *}$ \\
& Sig. (2-tailed) & & .000 \\
& $\mathrm{~N}$ & 120 & 120 \\
\hline Position & Pearson & $-.773^{* *}$ & 1 \\
& Correlation & & \\
& Sig. (2-tailed) & .000 & \\
& $\mathrm{~N}$ & 120 & 120 \\
\hline
\end{tabular}

**. Correlation is significant at the 0.01 level (2tailed).

Table 4. Chi-Square Tests

\begin{tabular}{|c|c|c|c|}
\hline & Value & df & $\begin{array}{l}\text { Asymp. Sig. (2- } \\
\text { sided) }\end{array}$ \\
\hline Pearson Chi-Square & $1.077 \mathrm{E} 2^{\mathrm{a}}$ & 7 & .000 \\
\hline Likelihood Ratio & 96.651 & 7 & .000 \\
\hline $\begin{array}{l}\text { Linear-by-Linear } \\
\text { Association }\end{array}$ & 71.031 & 1 & .000 \\
\hline $\mathrm{N}$ of Valid Cases & 120 & & \\
\hline
\end{tabular}

a. 8 cells $(50.0 \%)$ have expected count less than 5 . The minimum expected count is .17 . 
What is noticed here is that the distribution of power is not extremely bipolar. Thus, by using Likert scale, it was seen as a range of scaling between the highest and lowest values.

Table 5. There do not exist a general organizational climate that encourages

Delegation and Empowerment

\begin{tabular}{|c|c|c|c|c|}
\hline \multicolumn{5}{|l|}{ Count } \\
\hline & & \multicolumn{2}{|c|}{$\begin{array}{l}\text { Delegation \& } \\
\text { Empowerment }\end{array}$} & \multirow[b]{2}{*}{ Total } \\
\hline & & 1 & 2 & \\
\hline \multirow[t]{3}{*}{ Position } & Principal & 14 & 6 & 20 \\
\hline & Teacher & 36 & 64 & 100 \\
\hline & tal & 50 & 70 & 120 \\
\hline
\end{tabular}

$64 \%$ of the teachers consider that a general organizational climate that encourages delegation and empowerment do not exist. On the other hand, $6 \%$ of principals reported the same. According to teachers, the decision making is considered in the hands of principals.

According to Table 6, the observed statistics of chi-square test is 7.927 with freedom degree 1 . Since the significance show 0,005 , the second hypothesis was proven.

Table 6. Chi-Square Tests

\begin{tabular}{|c|c|c|c|c|c|}
\hline & Value & Df & $\begin{array}{l}\text { Asymp. Sig. } \\
\text { (2-sided) }\end{array}$ & $\begin{array}{l}\text { Exact Sig. (2- } \\
\text { sided) }\end{array}$ & $\begin{array}{l}\text { Exact Sig. (1- } \\
\text { sided) }\end{array}$ \\
\hline Pearson Chi-Square & $7.927^{\mathrm{a}}$ & 1 & .005 & & \\
\hline Continuity Correction ${ }^{\mathrm{b}}$ & 6.590 & 1 & .010 & & \\
\hline Likelihood Ratio & 7.888 & 1 & .005 & & \\
\hline Fisher's Exact Test & & & & .006 & .005 \\
\hline $\begin{array}{l}\text { Linear-by-Linear } \\
\text { Association }\end{array}$ & 7.861 & 1 & .005 & & \\
\hline $\mathrm{N}$ of Valid Cases ${ }^{\mathrm{b}}$ & 120 & & & & \\
\hline
\end{tabular}

a. 0 cells $(.0 \%)$ have expected count less than 5 . The minimum expected count is 8.33 .

b. Computed only for a $2 \times 2$ table

How can this be explained? Principals are reluctant when it comes to the participation of teachers in decision making process. Also, the organization creates fewer opportunities for participating in trainings. This goes in opposition with the government initiatives. The internship training for the professional development of teachers has been reported not to be enough.

There might be several obstacles for delegation and empowerment. In practice, the use of empowerment can create various problems and barriers. 
There are no ready recipes for management or leadership. Principals need to be familiar with management techniques and managerial styles, and should make use of them depending on the situation. It may happen that the empowerment is used in unfavorable and inappropriate situations. Hence, the outcome will not be functional. We recall here that theorists of the Situational Leadership Theories emphasize that a leader will be effective if he takes into account the situational factors. Sometimes, subordinates' characteristics, the perception of leaders on their power, the nature of work, or other important elements may not be appropriate to apply empowerment. So empowerment does not necessarily have to be applied in every case or every circumstance. Recalling the theories of Vroom- Jago, that of Path-goal, etc., the leader selects the style depending on the needs of the situation in which it is located. Certain situations may require individual principal decision-making or a style of direction. Also, not all principals can be open to sharing or distributing power. Some may perceive that their power will be dissolved, lose its value, its weight, and will not be sufficiently powerful. This can be psychologically damaging to some principals and at the same time serves as a barrier to the ability of teachers. Some principals may perceive the great use of power as much needed to do their jobs.

Organizations should be aware that it is unrealistic to expect leaders to distribute power to others when negative consequences of this action will fall on leaders. It should be considered whether or not the teachers are ready to assume responsibility, possess the necessary qualifications, experience or knowledge. If they are not ready, then empowerment is improper because the consequences would fall directly on the principal.

Coming to the most used power bases by principals, it is reported that the top three on the list include: legitimate power (95 percent agreement), power of expertise ( 82 percent agreement), and information power (74 percent agreement). Most frequently, power basis used by teachers are expertise power (96 percent agreement), referent power (87 percent agreement), and information power (79 percent agreement). Expert power is exercised by both principals and teachers. This power base can help a lot in holding the power, and making it unsubstituted in the organization. If we focus on the power bases used by teachers, we see that all of them are derived by individual characteristics and not from hierarchical position within the school.

\section{- Conclusion and Recommendations}

Through this study, we increased our knowledge about the leadership of principals, their use of power, and how it has a significant impact on the effectiveness of teachers. This, therefore, leads us to a better understanding of the dynamics, roles, and strategies that a school should design for a better performance. Our findings create a clearer picture of the power bases used by 
principals. Moreover, they throw light on distribution of power among teachers and the climate for empowerment. Both of our hypotheses were confirmed by our research findings. There exist moderate correlation between the position in the organization and the perceived level of power. Secondly, there do not exist a general organizational climate that encourages delegation and empowerment.

Consequently, we think that effective leadership is based not only on having power, but on how the leader uses power. We recommend to principals that by gaining effective leadership experience, they can apply the essence of all the basics of power in such a way as to benefit the teachers and the school. Different scholars have argued that true effective leaders are able to use all the basics of power to a certain extent by setting a balance in their use. Effective principals should combine the different sources and bases of power by selecting them according to appropriate cases, situations, and contexts. To other researchers, we recommend that the sample of the study should be extended in the future and should include all the high schools in Albania.

\section{References:}

1. Aguinis, H., Simonsen, M. M., \& Pierce, C. A. (1998). Effects of nonverbal behavior on perceptions of power bases. Journal of Social Psychology, 455-465.

2. Arendt, H. (2006). Gjendja Njerëzore. Tiranë: Ipls\&Dita 2000.

3. Bandura, A. (1978). Reflections on self-efficacy. Advanced Research Therapy, 237-269.

4. Bass, B. (1981). Stogdill's handbook of leadership. New York: The Free Press.

5. Blase, J. (1988). The teachers' political orientation vis-a-vis the principal: The micropolitics of the school. Në J. H. (Eds.), The politics of reforming school administration. New York: Falmer Press.

6. Blase, J. (1988). The teachers' political orientation vis-a-vis the principal: The micropolitics of the school. Në I. J. (Eds.), The politics of reforming school administration. New York: Falmer Press.

7. Bolin, F. S. ( 1989). Empowering leadership. Teachers College Record, 81-96.

8. Botha, R. (2004). Excellence in leadership: demands on the professional school principal. South African Journal of Education, 239-243.

9. Boulding, K. E. (1989). Three Faces of Power. Newbury Park, California: SAGE.

10. Bredeson, P. V. (1989). Redefining leadership and the roles of school principals: Responses to changes in the professional worklife of teachers. The High School Journal, 9-20. 
11. Brewster, C., \& Railsback, J. (2003). Building trusting relationships for school improvement: Implications for principals and teachers. Portland, OR: Northeast Regional Educational Lab.

12. Dahl, R. (1991). Democracy and its Critics. New Haven: Yale University Press.

13. Dalal, S., \& Rani, S. (2013). A Study of Leadership Quality in Teaching Profession. International Journal of Scientific and Research Publications, 3 (11).

14. Drake, T. L., \& Roe, W. H. (1999). The principalship. Upper Saddle River,NJ: Prentice-Hall.

15. Etzioni, A. (1964). Modern organizations. New Jersey: Prentice-Hall.

16. Etzioni, A. (1975). .A comparative analysis of complex organizations (rev. ed. New York: MacM;Ilian, Free Press.

17. Etzioni, A. (1978). Comparative analysis of complex organizations. In D. Hampton, C. Summer, \& R. Weber Organizational behavior and the practice of management. Glenview: Scott Foresman \& Co.

18. Feraj, H. (2004). Hyrje në Shkenca Politike. Tiranë: Pegi.

19. Forster, N. (2005). Maximum Performance: A Practical Guide to Leading and Managing People at Work. Cheltenham: Edward Elgar Publishing.

20. French, J. J., \& \& Raven, B. (1959). The bases of social power. In D. Cartwright (Ed.),Studies in Social Power. Ann Arbor: University of Michigan Press.

21. French, J. R., \& Raven, B. (1968). The bases of social power. In D. Cartwright, \& A. F. Zande, Group dynamics: Research and theory (fv. 259-269). New York: Harper \& Row.

22. Gunn, J., \& Holdaway, E. (1986). Perceptions of effectiveness, influence, and satisfaction of senior high principals. Educational Administration Quarterly, 22, 43-62.

23. Hasimja, E., \& Papa, E. (2008). Konceptimet e ndryshme të pushtetit. Nocione të Shkencave Politike, 40.

24. Institute of Education Development. (2016). National Report: Identification Of The Training Needs Of Leaders And Teachers Of Schools In Pre-University Education. Tirana.

25. Jamieson, D., \& O'Mara, J. (1991). Managing the workforce 2000. San Francisco: Jossey-Bass.

26. K.S, L., \& K, L. (2010). Learning from Leadership: Investigating the links to improved student learning. New York: Wallace Foundatio.

27. Kipnis, D. (1976). The powerholders. Chicago: University of Chicago Press.

28. Koxhaj, A. (2006). Aftësitë menaxheriale. Tiranë: Pegi. 
29. Krausz, R. (1986). Power and leadership in organizations. Tranactional Analysis Journal, 16, 85-94.

30. Lintner, J. D. (2008). The Relationship Between Perceived Teacher Empowerment. Auburn, Alabama.

31. Lyons, C. A., \& Murphy, M. J. (1994). Principal Self-Efficacy and the Use of Power. Annual Meeting of the American Educational Research Association. New Orleans, LA: Eric.

32. Marks, H. M., \& Louis, K. S. (1997). Does teacher empowerment affect the classroom? Theimplications of teacher empowerment for instructional practice and student academicperformance. Educational Evaluation and Policy Analysis, 245-275.

33. McNeil, K. (1978). Understanding organizational power: Building on the Weberian legacy. Administrative Science Quarterly, 65-90.

34. Rees, W. D., \& Porter, C. (2008). Skills of Management. United Kingdom: Cengage Learning EMEA.

35. Rinehart, J. S., Short, P. M., Short, R. J., \& Eckley, M. (1998). Teacher Empowerment and Principal Leadership: Understanding the Influence Process. Sage Journal.

36. Sayles, L. (1964). Managerial behavior: Administration in complex organizations. New York: McGraw-Hill.

37. Sergiovanni, T. J., \& Starratt, R. J. (2002). Supervision a redefinition (7th ed.). . New York: McGraw-Hill Book Company.

38. Short, P. M., \& Rinehart, J. S. (1992). Teacher empowerment and school climate. Paper presented at the Annual Meeting of the American Educational Research. San Francisco.

39. Short, P., \& Johnson, P. (1994). Exploring the links among teacher empowerment, leader power, and conflict. Education, 581-592.

40. Sturm, R. E., \& Antonakis, J. (2014). Interpersonal power: A review, critique, and research agenda. Journal of Management.

41. Thomas, K. W., \& Velthouse, B. A. (1990). Cognitive elements of empowerment: An "interpretive"'model of intrinsic task motivation. Academy of Management Review, 666-681.

42. Tjosvold, D. (1978). Cooperation and conflict between administrators and teachers. Journal of Research and Development in Education, 138147.

43. UNESCO. (2017). Shqipëria, Analiza e Politikës Arsimore: Çështje dhe Rekomandime.

44. Verderber, R. F., \& Verderber, K. S. (1992). Inter-act unsing interpersonal communication skills. Belmont: Wadsworth.

45. Weber, M. (1954). Max Weber on law in economy and society. Cambridge: Harvard University Press. 
46. Yukl, G. (1981). Leadership in organizations. Englewood Cliffs, NJ: Prentice-Hall.

47. Zogjani, A., Llaci, S., \& Elmazi, E. (2014). The Role Of Power In Effective Leadership and Followership: The Albanian Case . Romanian Economic and Busi, Vol. 9, No. 1, 89-102. 